\title{
ENREDOS DO ABUSO SEXUAL: ANÁLISE DO PROCESSO DE VIOLÊNCIA E ATENDIMENTO DE ADOLESCENTES NO MUNICÍPIO DE ALTAMIRA/PA
}

\section{PLOTLINES OF SEXUAL ABUSE: ANALYSIS OF PROCESS OF VIOLENCE AND CARE OF ADOLESCENTS IN THE MUNICIPALITY OF ALTAMIRA/PA}

\author{
Assis da Costa Oliveira* \\ Carine Costa Alves ${ }^{* *}$
}

\begin{abstract}
RESUMO: o presente artigo objetiva analisar as complexidades que envolvem o processo de produção do abuso sexual e as formas de atendimento institucional, com base na análise da história de vida de duas adolescentes, abusadas sexualmente, que residem no município de Altamira, estado do Pará. Inicialmente, discute-se a realidade histórica do abuso sexual nesse município, atentando para o caso dos meninos emasculados e o cenário atual influenciado pela construção da Usina Hidrelétrica de Belo Monte, e delimita-se, conceitualmente, o abuso sexual. Envereda-se, então, para a análise do período de infância das adolescentes, constatando-se a presença de fatores de risco que potencializaram a ocorrência do abuso sexual. Os processos de violência, cuja força simbólica se manteve para além do ato de revelação, promoveram pactos de silêncio entre os autores da violência e as vítimas. Ainda assim, a revelação, em ambos os casos, deveu-se a estratégias distintas de enfrentamento do abuso sofrido, o que acabou por gerar intervenção interinstitucional que acarretou a produção da revitimização, assim como a oferta do atendimento psicossocial por profissionais de uma única área científica, a Psicologia, sem garantir o trabalho interdisciplinar. No entanto, as adolescentes enfatizaram o caráter positivo da intervenção psicossocial, cujo maior resultado foi o fato de terem conseguido ressignificar as violências sofridas e estabelecer novos projetos de vida.
\end{abstract}

PALAVRAS-CHAVE: Abuso sexual. Atendimento institucional. Direitos das crianças e dos adolescentes. História de vida. Violência sexual.

ABSTRACT: This article aims to analyze the complexities involving the production process of sexual abuse and forms of institutional care, based on the analysis of the life history of two teenage girls, sexually abused in the municipality of Altamira, Pará state, where they reside. Firstly, it discusses the historical reality of sexual abuse in that municipality, paying attention to the case of the emasculated boys and to the current scenario influenced for the construction of the Hydroelectric Plant of Belo Monte, and conceptually defines sexual abuse. Subsequently, it analyzes the childhood of the two teenagers, noting the presence of risk factors that favor occurrence of sexual abuse. The violence cases, whose symbolic force

\footnotetext{
* Professor de Direitos Humanos da Universidade Federal do Pará - UFPA, Campus de Altamira. Mestre pelo Programa de Pós-Graduação em Direito (PPGD) da UFPA. Graduado pela Faculdade de Direito da UFPA. Secretário nacional do Instituto de Pesquisa Direitos e Movimentos Sociais. Coordenador Executivo da Comissão Municipal de Enfrentamento da Violência Sexual Contra Crianças e Adolescentes de Altamira/PA. Advogado.

*** Cientista Social pela Universidade Federal de Uberlândia (UFU). Pós-graduanda do Curso de Especialização em Educação, Diversidade e Sociedade da Universidade Federal do Pará - UFPA, Campus de Altamira. Revista da Faculdade de Direito - UFPR, Curitiba, vol. 59, n. 3, p. 197-223, 2014.
} 
remained beyond the act of revelation, did promote silence pacts between the rapists and their victims. Still, the uncovering, in both cases, was due to different strategies facing the abuse suffered, which finally led to inter-institutional intervention that, in its turn, led to the production of revictimization, as well as the provision of psychosocial care from a single scientific area - Psychology - without ensure interdisciplinary work. However, the abused adolescents emphasized the positive character of psychosocial intervention, whose main result was the fact that they managed to reframe the suffered violence and to establish new life projects.

KEYWORDS: Institutional intervention. Life history. Rights of children and adolescents. Sexual abuse. Sexual violence.

\section{INTRODUÇÃO}

A violência sexual se constitui em um dos principais problemas públicos a serem enfrentados pela sociedade e pelo Estado brasileiro na temática das crianças e dos adolescentes. Segundo os dados do Disque 100 referentes ao ano de 2013, tal violência foi a terceira com maior quantidade de denúncias no território nacional, atrás, apenas, dos casos de negligência e de violência física, respectivamente. Trata-se de 25,71\% (ou 31.895 denúncias recebidas) dos casos registrados pelo canal, sendo que a distribuição por subcategorias da violência sexual revela um total específico de abuso sexual ${ }^{1}$ de $83,44 \%$ (ou 26.613 denúncias recebidas) (BRASIL, 2013).

No campo dos direitos humanos, o abuso sexual insere-se no plano normativo dos direitos sexuais e apresenta-se como uma das piores formas de afetação ao desenvolvimento da criança e do adolescente, pois interfere negativamente na formação da sexualidade e do corpo, além de trazer danos psicossociais subjetivos à vítima. Para cada caso que chega a ser denunciado, um enredo específico de violência, de revelação e de atendimento institucional é estabelecido, configurando uma trajetória de produção do abuso sexual que se inicia muito antes do ato em si e que se prolonga para muito depois do término deste, conformando-se de maneira entrelaçada com a trajetória de vida dos sujeitos envolvidos, especialmente da vítima.

No presente trabalho objetiva-se analisar a história de vida, na modalidade tópica (dando ênfase a determinadas etapas), de duas adolescentes abusadas sexualmente, residentes no município de Altamira, sudoeste do estado do Pará. Uma delas, Alvina ${ }^{2}$, foi alvo de abuso sexual intrafamiliar; a outra, Giselda, da modalidade extrafamiliar ${ }^{3}$.

\footnotetext{
${ }^{1}$ A conceituação do abuso sexual será feita no item 1 do presente artigo.

${ }^{2}$ Os nomes são fictícios, para resguardar a identidade das entrevistadas.

${ }^{3}$ Novamente, informa-se que as conceituações de abuso sexual intrafamiliar e abuso sexual extrafamiliar encontram-se definidas no item 1 do presente artigo. 
A metodologia da história de vida tem se apresentado propícia aos estudos de pessoas nos vários contextos sociais, pois oferece possibilidade de compreender as tramas vividas, as situações, grupos, processos, percepções e envolvimentos relativos ao objeto de estudo; no caso em questão, relativo ao abuso sexual de adolescentes.

Adota-se uma posição crítica sobre o método da história de vida, percebendo a história narrada sobre a vida a partir do que Bourdieu denomina como "noção de trajetória como série de posições sucessivamente ocupadas por um mesmo agente (ou um mesmo grupo) num espaço que é ele próprio um devir, estando sujeito a constantes transformações" (2006, p. 189. Grifos do autor). É dizer, menos como uma sucessão de acontecimentos cronológicos, e mais no sentido de "colocações e deslocamentos no espaço social" (BOURDIEU, 2006, p. 190. Grifos do autor) perceptíveis pelos sujeitos a partir da inserção de suas trajetórias dentro de um conjunto de relações objetivas construídas com outros sujeitos no mesmo campo social, e que interagem nos mesmos espaços de conformação destas posições.

Desse modo, foram entrevistadas duas adolescentes (ou jovens), nas idades entre 15 e 19 anos, que sofreram abuso sexual durante uma parte da vida e em contextos distintos, uma morando no meio rural (Alvina) e outra na área urbana do município (Giselda). O acesso às adolescentes demandou a colaboração do Centro de Referência Especializada da Assistência Social de Altamira (CREAS/Altamira), instituição que as acompanhava na época das entrevistas, ambas realizadas em junho de $2012^{4}$. Nesse sentido, a escolha das adolescentes ocorreu em consonância com a avaliação das profissionais do CREAS, que definiram as vítimas que, segundo informaram, teriam "melhores condições psicológicas" para falar sobre suas vidas.

No primeiro capítulo, discute-se o contexto histórico de produção do abuso sexual contra crianças e adolescentes no município de Altamira, além da reflexão teórica sobre a própria definição de abuso sexual. Do segundo até o sétimo capítulo, um conjunto de elementos (percepção da infância; condições socioeconômicas; escolaridade; processo de violência; revelação e denúncia; tratamento psicossocial e perspectivas de vida pósatendimento) de diferentes etapas da história de vida das adolescentes entrevistadas é

\footnotetext{
${ }^{4}$ A coleta de dados desenvolveu-se no âmbito das atividades do projeto "Rodas de Direito: diálogo, empoderamento e prevenção no enfrentamento da violência sexual contra crianças e adolescentes", coordenado pela Universidade Federal do Pará, em parceria com a Fundação Tocaia e o Sociart, e com financiamento da Secretaria de Direitos Humanos da Presidência da República (SDH/PR). No entanto, as análises empreendidas no presente artigo representam um aprofundamento teórico e analítico não presente no relatório final da pesquisa (PINHO; OLIVEIRA, 2013), consistindo em discussões que se embasam nas entrevistas coletadas durante o período da pesquisa para produzir novos argumentos e problematizar situações até então não priorizadas ou identificadas.
} 
analisado para compreender o antes, o durante e o depois do abuso sexual na vida das entrevistadas.

\section{ABUSO SEXUAL: CONTEXTO LOCAL E CONCEITUAÇÃO}

Quando o abuso sexual tornou-se um problema público no município de Altamira, sudoeste do Pará, foi sob o ímpeto de uma tragédia histórica: o caso dos meninos emasculados de Altamira. As 26 crianças assassinadas e/ou seriamente violentadas ${ }^{5}$, ao longo dos anos de 1989 e 1993, tinham, muitas delas, seus órgãos sexuais extirpados e evidente presença de violência sexual, configurando-se numa sequência de crimes bárbaros que visibilizavam à sociedade e ao poder público as consequências que múltiplas formas de violência podiam acarretar às vítimas, seus familiares e à população como um todo (LACERDA, 2012, 2013 e 2014).

De 1989 a 2014 muitas coisas mudaram, e outras não, no município. O envolvimento de pessoas do povo, lideranças sociais e entidades na apuração e punição dos réus do caso dos meninos emasculados de Altamira fez surgir diversas organizações sociais e instituições públicas $^{6}$ que passaram a colocar a situação da infância e da adolescência como pauta prioritária de disseminação à opinião pública e de reivindicação política junto ao Estado.

Nesse aspecto, é possível dizer que as tragédias têm uma função pedagógica - elas ajudam a compreender o que nunca mais pode ocorrer, responsabilizam o poder público para que possa encontrar instrumentos e estabelecer políticas que sirvam de maneira preventiva, para o impedimento de novas situações, e que impulsionem os trabalhos necessários para a correta solução do problema em evidência.

\footnotetext{
${ }^{5}$ A quantidade de vítimas da emasculação e outras violências no período é uma questão em disputa. Segundo Lacerda (2012, 2013 e 2014), enquanto a Polícia Civil instaurou inquéritos policiais para investigar as causas da morte de sete vítimas, a Justiça Estadual acolheu as ações propostas e deu andamento processual e julgamento em relação ao assassinato de cinco dessas vítimas, enquanto o movimento social reivindica o reconhecimento de 26 casos com traços semelhantes no período, consistindo "na abordagem de meninos por um estranho, em diferentes pontos da cidade, que lhes oferecia uma oferta de trabalho ('tenho sapatos para engraxar'), de uma brincadeira ('vamos ali caçar papagaios') ou de uma comida ('logo adiante tem mangas mais maduras'). Depois de afastados das áreas mais movimentadas, os meninos eram sedados - uma substância de cheiro forte era colocada em seus narizes, com um pano - torturados (foram observados em alguns corpos queimaduras de cigarro, pulsos cortados, couro cabeludo arrancado) e mutilados na região da genitália" (LACERDA, 2014, p. 195). No presente trabalho dar-se-á concordância com o quantitativo numérico apresentado pelo movimento social.

6 Trata-se da criação do Conselho Municipal dos Direitos da Criança e do Adolescente de Altamira (CMDCA/Altamira), fundado em 1991, sendo o primeiro do estado do Pará; do Movimento Contra a Violência e em Favor da Vida, criado em 1992 e contendo representantes de organizações populares, Igreja Católica e escolas, sendo que no mesmo ano foi fundado o Conselho Tutelar de Direitos de Altamira; e do Comitê em Defesa da Vida da Criança Altamirense, criado em 1993 pelas mães e familiares das vítimas dos crimes de emasculação e por pessoas solidárias à causa (LACERDA, 2012, 2013 e 2014; VIEIRA; OLIVEIRA, 2014).

Revista da Faculdade de Direito - UFPR, Curitiba, vol. 59, n. 3, p. 197-223, 2014.
} 
Mais de duas décadas se passaram desde a ocorrência da tragédia dos meninos emasculados de Altamira e, desde 2010, os dados estatísticos têm demonstrado um aumento crescente dos casos de violência sexual contra crianças e adolescentes. Segundo Oliveira e Pinho (2014), a análise dos 258 processos judiciais existentes no Fórum de Justiça da Comarca de Altamira, que versam sobre crimes sexuais contra crianças e adolescentes, correspondente ao período de 1957 a 2013, revela uma evolução histórica da quantidade de casos que ingressaram anualmente, numa média que passou de 10 processos por ano na primeira década do século XXI para 30 processos por ano apenas nos quatro primeiros anos da segunda década do referido século. Uma triplicação que tem como um de seus principais fatores o processo de implantação da Usina Hidrelétrica de Belo Monte (UHE Belo Monte), que acarretou a intensificação da migração populacional para o município, especialmente de homens solteiros e famílias em situação de vulnerabilidade socioeconômica, na esperança de conseguirem emprego e melhores condições de vida no megaempreendimento ${ }^{7}$.

No entanto, é interessante observar, nos processos judiciais analisados por Oliveira e Pinho (2014), que 233 ou 92\% deles são relativos a tipos penais conceituados como abuso sexual. Nesse sentido, o abuso sexual encontra maior visibilidade institucional ${ }^{8}$ e, por isso mesmo, intervenção socioestatal no cenário municipal, o que resulta numa maior possibilidade de acesso das vítimas aos serviços de atendimento, tanto quanto de punibilidade dos autores dos abusos.

Conceitualmente, o abuso sexual se insere como uma das modalidades de violência sexual contra crianças e adolescentes. Para López (2010), Pedersen e Grossi (2011) e Santos e Ippolito (2011), trata-se de qualquer forma de contato e/ou atividade sexual entre um adulto e uma criança ou adolescente, em que o adulto possui uma condição de responsabilidade, confiança e/ou poder, utilizados para obter sua satisfação sexual e promover estimulações

\footnotetext{
${ }^{7}$ A implantação da UHE Belo Monte não é o único fator explicativo do aumento de casos de violência sexual contra crianças e adolescentes. De acordo com Oliveira e Pinho (2014, p. 110): “[c]ertamente, é necessário realizar o recorte analítico de tais dados levando em conta as três hipóteses apresentadas no relatório anterior (PINHO e OLIVEIRA, 2013), quais sejam: (1) serem efeitos negativos decorrentes da construção da UHE Belo Monte, ante o aumento de contingente populacional em rápido período temporal, sobretudo de homens solteiros e famílias em situação de vulnerabilidade socioeconômica; (2) a implantação de novas instituições ao longo dos anos que possibilitou uma melhoria da atuação do SGD no trabalho de encaminhamento dos casos de violência sexual contra crianças e adolescentes; e, (3) as campanhas de sensibilização historicamente desenvolvidas no município, mas que ganharam uma intensificação das ações ante a criação da Comissão Municipal de Enfrentamento da Violência Sexual Contra Crianças e Adolescentes, proporcionando a disseminação de informações relativas aos direitos das crianças e dos adolescentes, e ao enfrentamento da violência sexual, que podem ter contribuído para um aumento das denúncias, e não dos casos reais".

${ }^{8}$ Isto porque, como ressaltam Oliveira e Pinho $(2014$, p. 112), "[e]m termos de porcentagem comparativa, identifica-se a presença de apenas $8 \%$ dos processos judiciais tratando de crimes relativos à exploração sexual comercial de crianças e adolescentes, o que entra em descompasso com os dados apurados na pesquisa de campo realizada na cidade para apurar os cenários e territórios da exploração sexual comercial, revelando que tais casos ainda não conseguem ser denunciados ou publicizados a ponto de garantir o acesso à justiça".
} 
sexuais na criança ou adolescente ${ }^{9}$, sendo que estes não estão em condição de dar consentimento e nem possuem desenvolvimento sexual adequado.

Internamente, o abuso sexual possui três linhas distintas de caracterização, orientadas em decorrência do tipo de vínculo entre o autor e a vítima da violência sexual. As formas são descritas como intrafamiliar, intrarrede social e extrafamiliar (SANTOS; IPPOLITO, 2011). Desse modo, quando os autores são parentes da vítima, ou seja, pessoas com vínculos familiares, diz-se que o abuso ocorreu numa perspectiva intrafamiliar. Por outro lado, se forem pessoas que convivem nos espaços de socialização da família e que possuem outro tipo de vinculação social com a vítima (amigo, vizinho ou conhecido), fala-se em abuso sexual intrarrede social. Por fim, caso sejam pessoas ligadas a outros espaços de socialização (escolas, igrejas, consultórios médicos, entre outros), e também desconhecidos, há o chamado abuso extrafamiliar.

As distinções tipológicas do abuso sexual não caracterizam apenas os sujeitos envolvidos. Refletem também aspectos que interferem diretamente nos impactos que o abuso pode ter no desenvolvimento psicossocial, no processo de revelação e nas formas de atendimento, além de, como ressaltam Sahin e McVicker (2011), influir na própria percepção que a vítima tem do abuso e das causas que levaram à sua ocorrência. Segundo Royer (1992), não se pode tratar do trauma infligido à vítima sem pensar no contexto social no qual ele ocorre, especificamente na situação da criança/adolescente junto à sua família e no impacto que o abuso terá após a revelação, com consequências que são geradas em cada reação e com a decisão a ser tomada por todos os envolvidos, desde os familiares até os médicos, os juízes e os meios de comunicação.

Certamente, o abuso sexual, como manifestação de violência, é uma forma explicativa de um processo social que não se encerra na realização do ato ou no atendimento às vítimas e aos autores. Trata-se de uma violência que deixa marcas profundas, pois interfere na sexualidade da criança ou do adolescente e, portanto, nos sentimentos, pensamentos e zonas corporais mais íntimos, assim como, em muitos casos, em relações de parentesco ou de confiança das pessoas mais próximas das vítimas, como pais, tios e padrastos, que afeta suas histórias de vida e, ao mesmo tempo, pode ser explicada a partir delas.

\footnotetext{
9 O abuso sexual também pode ocorrer entre crianças e/ou adolescentes quando, por questão de idade ou desenvolvimento, um deles se encontra em posição de responsabilidade, confiança e/ou poder (LÓPEZ, 2010).

Revista da Faculdade de Direito - UFPR, Curitiba, vol. 59, n. 3, p. 197-223, 2014.
} 


\title{
2 PERCEPÇÕES SOBRE A INFÂNCIA
}

Segundo relataram, Giselda viveu a infância com a família, com os irmãos e irmãs, e era cuidada e protegida em horário integral, conforme os arranjos da família, dentro e fora de casa. Já Alvina viveu a infância com a avó, mas, no período de escolarização, entre os seis e sete anos, mudou-se para a casa dos pais, onde passou definitivamente a viver na infância, para estudar.

\begin{abstract}
[...] a gente sempre morou nesse bairro desde criancinha [...] minha mãe não deixava muito eu ficar na rua não. Eu ficava mais quando ela tinha que trabalhar e ficava mais tarde aí meu pai chegava mais cedo, umas cinco horas aí que ele deixava assim, mas ela não deixava não, aí era uma ou outra vez que eu brincava na rua [...] quando eu saía eu brincava de tudo, todas as brincadeiras de criança. Acho que de todas as brincadeiras que eu gostava mais era do taco, gostava também da bandeirinha, mas como eu tô te falando era mais difícil porque minha mãe não gostava, aí quando eu saía, digamos assim, escondido pra ficar na coleguinha lá, ichi, aí era taca na certa, ela não gostava não que eu saísse (GISELDA. Transcrição literal).
\end{abstract}

Quando criança morava na roça mesmo, minha avó tinha fazenda, e aí eu morava com ela. [...] morava eu, a minha avó e meu avô mesmo. Aí dava uns quinhentos metros mais ou menos numa baixada morava meu tio. [...] eu morei com minha avó até os sete anos de idade, aí nos meus sete anos, minha mãe foi me buscar pra vir pra vila mesmo estudar, e aí eu só ia nas férias, meio de ano e final de ano pra lá. [...] Acho que foi a melhor parte da minha vida foi com eles. [...] Não, não tinha amigos, só tinha duas primas e um primo e meu avó era tudo, foi um que nunca levantou nem a mão pra triscar em mim. Faz muita falta pra mim. Acho que se ele tivesse vivo hoje eu não tava nesse... [silêncio] (ALVINA. Transcrição literal).

Como se percebe, a compreensão das entrevistadas sobre o período da infância é marcada pela posição protetiva e afetiva que assumiam seus familiares. Cada uma apresenta convivência em diferentes arranjos familiares - Giselda com os pais; Alvina com os avós e, posteriormente, com os pais -, o que apenas ressalta o caráter socioafetivo que conforma o núcleo do reconhecimento sociojurídico das configurações familiares (ALBUQUERQUE JÚNIOR, 2007; DIAS, 2007; GROENINGA, 2003).

Num contexto discursivo no qual a família passa a ser percebida de forma desbiologizada, é dizer, deslocando seu núcleo fundamental da pertença e estruturação para o afeto $^{10}$, com o reconhecimento de outras configurações sociais de arranjos familiares que as relações sexuais e socioeconômicas delineiam (famílias homoafetivas e monoparentais, por exemplo), a família passa a ser vista, ao mesmo tempo, como uma função, lugar simbólico ocupado por indivíduos legitimados pelas funções que exercem, e um direito, o direito

\footnotetext{
${ }^{10}$ A compreensão psicanalítica da dinâmica do afeto possibilita a ampliação de sua dimensão para além da relação com os sentimentos amorosos (GROENINGA, 2003; LACAN, 1981; PEREIRA, 2003), inclusive no âmbito familiar, contribuindo para a desconstrução crítica da representação dualista baseada nas classificações discriminatórias de famílias estruturadas e não estruturadas.
}

Revista da Faculdade de Direito - UFPR, Curitiba, vol. 59, n. 3, p. 197-223, 2014. 
fundamental à convivência familiar, constitucionalmente garantido no artigo 227 (BRASIL, 1988), com a garantia da proteção e dos cuidados parentais e comunitários.

De outra parte, nota-se uma distinção nos círculos de amizade, com Giselda tendo um grupo maior de amigos, cuja interação se dava, prioritariamente, no espaço da rua, enquanto Alvina tinha um grupo de amigos constituídos basicamente por familiares da mesma geração.

\section{CONDIÇÕES SOCIOECONÔMICAS E ESCOLARIDADE}

As famílias das entrevistas são bem modestas, vivem do trabalho temporário, braçal, e/ou das produções na roça. A situação material das duas jovens não é a de privilégios sociais, mas de enfrentamentos de adversidades.

\footnotetext{
Minha mãe sempre lavou roupa pra fora, pra poder sustentar a gente. Ele [pai] já foi eletricista, de tudo. Pedreiro [...] (ALVINA. Transcrição literal).

Ele [pai] trabalha na prefeitura, ele é encarregado, assim ele trabalha na cidade, serviço geral, construção de alguma coisa, mais na construção, reforma também, na cidade é isso, não digo pedreiro, mas um que entende, um pouco de tudo assim, ele é. Mas ele num tem uma profissão fixa assim do que ele é. Minha mãe trabalha em casa de família (GISELDA. Transcrição literal).
}

De acordo com Erolin, Wieling e Parra (2014), as condições econômicas, principalmente as ligadas à pobreza e ao desemprego, incluem-se entre os fatores familiares e comunitários que influenciam no bem-estar da criança e podem se converter numa situação de risco ou de vulnerabilidade sexual. Nesse ponto, não se trata de entender a pobreza em si como uma situação problema, mas de perceber de que forma o ambiente e as relações sociais são prejudicadas pelo fator econômico, ao ponto de gerar processos sociais que evidenciam riscos às crianças e aos adolescentes, sobretudo quando aliados com outros determinantes, como uso de drogas e alta incidência de violência social na comunidade/bairro.

Por isso mesmo, Pedersen e Grossi (2011) apontam que as violências sexuais precisam ser relacionadas com as violências estruturais que se reproduzem na sociedade, dentre as quais as que levam em conta as relações de gênero, intergeracional e socioeconômica, e que extravasam e, ao mesmo tempo, reproduzem-se no âmbito das relações familiares e comunitárias. Assim, enfatizam as autoras que a vulnerabilidade social pode ser um fator determinante para o desencadeamento de violência sexual, "uma vez que as consequências da desigualdade social gerada pelo mundo capitalista contribuem para a 
precarização e deterioração de suas relações afetivas e parentais" (PEDERSEN; GROSSI, 2011, p. 30).

No plano específico das histórias de vida analisadas no presente artigo, não ficaram demonstradas conexões diretas entre a condição econômica atribuída pelas entrevistadas às suas famílias e os abusos sexuais sofridos, apesar de as adversidades enfrentadas indicarem dificuldades para a manutenção de um bem-estar adequado às adolescentes. No entanto, o fator econômico relaciona-se indiretamente com o nível de escolaridade identificado nas famílias das vítimas e com elas mesmas, além de revelar a falta de equipamentos e políticas públicas no bairro/comunidade em que residem, contribuindo para a impossibilidade de um atendimento célere ou inicial após os abusos sofridos.

A mãe de Giselda estudou até a $3^{\mathrm{a}}$ série do ensino fundamental e o pai começou o ensino médio, mas não terminou. A mãe de Alvina também estudou as primeiras séries do ensino fundamental, assim como o pai.

A baixa escolaridade da geração dos pais se repete na segunda geração, a dos filhos, que compreende as vítimas, irmãos e irmãs. Eles também tiveram pouco sucesso escolar, pois, embora tenham frequentando a escola por determinado período, dela logo desistiram, para casar, trabalhar etc. A escola, de toda maneira, ao invés de ter sido um local de investimento simbólico para o conhecimento e a ascensão social, foi vivenciada como um espaço de medo, afastamento e exclusão, tanto pelos irmãos das vítimas, quanto por elas mesmas.

\footnotetext{
Num cheguei a parar [de estudar] não. Se não me engano eu cheguei a repetir a primeira série uns dois anos mais ou menos, dois, três anos por aí assim, porque eu não gostava de ir pro colégio. Aí depois que eu desencalhei dali, aí foi até o ano passado, sem repetir (ALVINA. Transcrição literal).

[...] eu gostava dos professores, só que assim, parece uma coisa, porque assim, eu sempre tive um pouco de problema na escola, mas não assim de nota, mais de amizade porque eu era fechada, era tímida era assim, era quieta, aí os meninos acabavam mexendo comigo, e as meninas também, isso porque eu não ficava no meio da bagunça. [...] era só eu e minha coleguinha, a gente num falava com ninguém na sala, era só eu e ela, nós ficava apavorada quando era pra fazer trabalho em grupo porque a gente não conversava com ninguém, a gente ficava ali isolada na sala, sentava na frente [...] (GISELDA. Transcrição literal).
}

Em relação à interação das vítimas com a escola, podemos indicar que elas tiveram trajetórias bem diversas. Giselda era bastante tímida, retraída, mas se declarou estudiosa, inteligente, recebendo, nas avaliações escolares, somente conceitos bons, conforme indicou. Já Alvina teve uma trajetória mais conturbada e, podemos aventar, com interferências dos processos de violência intrafamiliar sofridos concomitantemente ao percurso escolar. A 
adolescente estava, no período da pesquisa e coleta dos dados, com 19 anos de idade, e ainda cursava a escola para terminar o ensino fundamental.

Observa-se que há um descompasso entre o sucesso escolar e o poder de discernimento das jovens quanto às situações adversas enfrentadas, ou seja, as boas/más notas da escola se relacionam com um tipo de aprendizagem que pouco, ou quase nada, contribuiu para a compreensão dos processos de opressão que se opunham contra elas.

Está-se diante de uma dupla constatação, uma conclusiva e outra hipotética. A primeira, conclusiva, é de que ao longo do período de abuso sexual cometido contra as adolescentes nenhum professor ou membro da comunidade escolar se apercebeu ou suspeitou dos fatos; logo, não foram capazes de detectar as situações a tempo de encurtar os sofrimentos e danos que os atos causaram às adolescentes. De outra parte, uma questão hipotética, é a de que as escolas frequentadas pelas vítimas não ofereceram conteúdos de educação para a sexualidade e de prevenção ao abuso sexual que lhes proporcionassem conhecimentos e instrumental necessários para melhorarem suas habilidades de autoproteção.

De acordo com Landini (2011) e Padilha e Williams (2011), as funções dos profissionais da educação - e da escola enquanto espaço de convivência social - em relação ao abuso sexual estruturam-se em dois campos complementares: (1) de percepção e notificação ${ }^{11}$ dos casos de abuso sexual ocorridos com as crianças e os adolescentes, sendo necessário capacitar os educadores para que identifiquem os sinais físicos, comportamentais e sociais ${ }^{12}$ que revelem uma suspeita ou convicção da ocorrência da violência, e também para que tenham suporte para realizar o atendimento inicial aos estudantes, assim como dar o apoio necessário ao Conselho Tutelar de Direito para a atuação em rede; (2) o fomento à educação para a sexualidade, no sentido de oferecer aos educandos informações sobre sexualidade, direitos sexuais e violência sexual, para assim empoderá-los quanto às medidas a serem

\footnotetext{
${ }^{11}$ Notificação que se tornou obrigatória, a ser feita ao Conselho Tutelar de Direito, ante disposição dos artigos 13 e 56 do Estatuto da Criança e do Adolescente (ECA - Lei no 8069/90) (BRASIL, 1990a). Porém, como atenta Landini (2011, p. 89): “[a]pesar da obrigatoriedade, contudo, é baixo o número de notificações efetivamente realizadas por seus profissionais [da educação e da saúde]. Na visão de Silva, Ferriani e Medeiros (2008, p. 206), isso sugere o pouco conhecimento, envolvimento e sensibilização desses profissionais em relação à temática da violência sexual contra crianças e adolescentes. A tarefa colocada é a do estabelecimento de ações preventivas e assistenciais exequíveis para o enfrentamento desta problemática".

12 “Os maus-tratos podem ser sinalizados através de marcas físicas no corpo ou de distúrbios do comportamento, e a suspeita pode ser despertada a partir de 'desenhos das crianças, especialmente crianças pequenas, por composições escolares de crianças mais velhas, por comportamento sexualizado em todas as idades, por referências verbais ou por outras formas de comunicação direta ou indireta" (LANDINI, 2011, p. 89-90).

Revista da Faculdade de Direito - UFPR, Curitiba, vol. 59, n. 3, p. 197-223, 2014.
} 
adotadas para prevenção ou atuação diante de situações de risco, além de garantir-lhes o entendimento de sua sexualidade e das formas de exercê-la de maneira responsável ${ }^{13}$.

No entanto, nas histórias de vida analisadas, parece que não houve nenhuma das duas modalidades de atuação protetiva da escola, o que pode ter contribuído para a percepção negativa que as entrevistadas (e seus familiares) têm da escola, de não identificar aspectos marcantes para suas vidas nos conteúdos e relações sociais desenvolvidos nesse espaço no período prévio e concomitante aos abusos sexuais.

\section{PROCESSO DE VIOLÊNCIA}

A violência sexual acometida às jovens possui pontos de divergência e de semelhança. A situação enfrentada por Giselda, de abuso sexual extrafamiliar, fez com que ela vivesse meses de terror e de angústia, sem entender por que aquilo estava acontecendo com ela e justamente num local de sua total confiança: a igreja.

[...] ele ficava falando pra mim fazer de tal jeito, pra mim não dar bandeira, disfarçar bem, você não imagina o que era isso oh, eu tá ouvindo aquelas coisas horríveis, eu chorava e chorava de madrugada que só, eu acordava com olho inchado e jogava bem água na minha cara pra minha mãe não ver que eu tava chorando (...) eu morria de medo, imagina uma pessoa que vivia de bem com a vida depois saber que tava prestes a morrer a qualquer momento (GISELDA. Transcrição literal).

Giselda foi abusada sexualmente por um pastor de sua igreja, um rapaz jovem, entre 26 e 27 anos, conforme indicou, que, aproveitando-se de sua imaturidade diante da vida e da sexualidade, convenceu-a a ter relações sexuais. Ela, que nunca havia sequer se aproximado de um rapaz, que quase não tinha amigos e que pouco saía de casa, apenas estudava e ia para a igreja, e que tinha uma família bastante protetiva. Ainda assim, não foi difícil convencê-la, pois ela não imaginava o que estaria por vir. E, quando manifestou sua não aceitação dos abusos sofridos, passou a ser ameaçada de morte, vivendo a partir daí um pesadelo constante.

$\mathrm{O}$ caso de Alvina foi um processo de abuso sexual intrafamiliar com requintes de maus-tratos, agressões físicas e violência psicológica, conduzidos por alguém que ela, segundo relato, "nunca esperava": o pai biológico. Tanto é que Alvina afirma, em vários momentos, que tudo o que ela queria era entender o motivo daquela situação, mas isso ela nunca soube:

\footnotetext{
${ }^{13}$ Trata-se, segundo Padilha e Williams (2011, p. 129), de garantir uma atuação de prevenção primária da escola para "favorecer a aquisição de repertório capaz de evitar a exposição a risco de abuso sexual, ou retirar-se de uma situação potencialmente abusiva após a percepção do risco".
} 
[...] sofri muito. Sei lá, eu não ligava pra se eu ia apanhar não, eu só queria entender o porquê, entendeu? Queria entender dos meus quatorze anos em diante, o porquê disso [...] (ALVINA. Transcrição literal).

Alvina revela um corte temporal de mudança comportamental importante, perceptível por ela quanto ao tratamento que seu pai lhe oferecia até os 12 anos e depois desta idade:

\begin{abstract}
ah, até os meus doze anos foi [respira fundo buscando força para falar], era aquele pai atencioso, queria dá educação pros filhos, dá uma vida honesta, como muitos pais são por aí. Até meus doze anos era assim [...] Aí, com o tempo foi mudando, quando eu saía ele já tava no portão me esperando pra eu ir pra casa, eu não saía na porta de casa pra falar com minhas amigas que ele já tava brigando, apanhei muito, gostaria de entender o motivo, entendeu? Sempre queria ter entendido o motivo [pausa e lágrimas nos olhos]. Eu tenho, quase num dá pra perceber, eu tenho uma cicatriz no rosto, quase num dá pra ver, é desse lado assim [ela passa a mão do lado direito, ao lado do nariz, na bochecha], um prato quebrou no meu rosto, eu tinha uns quatorze anos de idade (ALVINA. Transcrição literal).
\end{abstract}

E, quando perguntado a ela o que sua mãe fez sobre a situação, informou que "minha mãe não podia fazer nada, minha mãe chegou a apanhar também dele" (ALVINA. Transcrição literal). Depois de um tempo sofrendo violência física, maus-tratos e abuso sexual, Alvina tentou fugir de casa, mas seu plano fracassou e ela acabou sofrendo mais violência nesse dia. Ela fala: "[e]u tinha vontade de matar, sabe que que é matar mesmo [rangendo os dentes ao falar sobre isso]. Uma vez até cheguei a falar pra mãe 'ou eu mato ele ou eu morro também"” (ALVINA. Transcrição literal)

No caso de Alvina, o abuso sexual durou dos 13 aos 17 anos, sempre induzido pelo uso de força física e/ou coação. Quanto à Giselda, a situação perdurou por alguns meses, inicialmente por meio de sedução e, posteriormente, de ameaça. Em ambos os casos, houve uma mescla, do abuso sofrido, com outros tipos de violência, como maus-tratos e ameaça.

Além disso, Alvina revela uma situação mais ampla de sujeitos violentados, em sua família, pelo pai - não somente a mãe, como informado acima, mas também seu irmão, foram alvos de violência física e doméstica, e isto, ressalta ela, contribuiu de maneira decisiva para que a mãe, mesmo sabendo o que o pai lhe forçava a fazer, não denunciasse a situação, ante o medo da retaliação; é dizer, de sofrer mais violência.

Santos e Dell'Aglio (2009), no trabalho investigativo junto a dez mães de vítimas de abuso sexual intrafamiliar, indicam que as mães se encontram tão envolvidas nessa situação quanto as próprias vítimas, podendo vivenciá-las enquanto vítimas, testemunhas ou perpetradoras. Segundo as autoras, a postura de indiferença, negação e/ou falta de apoio da mãe, quando da revelação do fato, está relacionada a um conjunto de fatores pessoais, tais como: continuidade do contato com o autor da violência sexual, dependência econômica, 
distanciamento emocional para com a(s) filha(s), violência doméstica sofrida, além do abuso sexual intrafamiliar que muitas das entrevistadas informaram terem sofrido no período da infância.

Portanto, não se pode compreender a reação materna sem contextualizá-la com determinados fatores que conduziram ou influenciaram a produção do comportamento, algo somente possível com a averiguação de sua história de vida. A violência perpetrada à criança/adolescente também incide sobre a mãe, fazendo-a estabelecer estratégias de sobrevivência e continuidade conjugal que, por vezes, estão em descompasso com os direitos das crianças e dos adolescentes, ao menos quanto à obrigatoriedade da denúncia.

Por outro lado, o processo de violência, pelo qual passaram as duas entrevistadas,

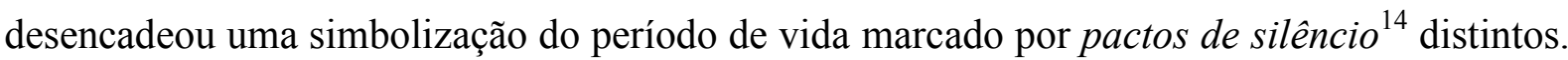
Para Giselda, era a impossibilidade de contar aos pais, devido às ameaças do autor. Alvina, por sua vez, estava certa de que seus familiares mais próximos sabiam o que se passava com ela, mas todos se calavam ante o temor de represálias que poderiam sofrer do agente, seu pai. Cada período estrutura-se em um cenário de ameaças e perigos que instituía às vítimas uma posição social de portadoras de segredos que não encontravam possibilidade de externalização, trazendo-lhes um sentimento de impotência constante.

O tempo no qual perdurou a manutenção desses segredos é o tempo de reprodução do abuso sexual e, portanto, de conformação de traumas e violências de maneira recorrente, que deixaram marcas físicas e psicológicas para o resto de suas vidas, cerceando-lhes a dignidade sexual e o desenvolvimento saudável da sexualidade.

\section{REVELAÇÃO E DENÚNCIA}

O processo e o contexto da denúncia dos casos analisados são bem distintos entre si. Na história de Alvina, a vítima, após anos de reprodução continuada do abuso sexual, viu a vida, por um instante, extremamente ameaçada, e, com isso, tomou coragem para lutar e enfrentar o medo que tinha do autor, resolvendo denunciar o fato para um parente externo à família nuclear, tal como relata:

\footnotetext{
${ }^{14}$ Segundo Lamour (1997), o silêncio ou o segredo da vítima só se mantém porque as ameaças tornam os efeitos da revelação ainda mais perigosos que o próprio ato em si. Tais perigos, segunda aponta, são tanto o temor pela punição, quanto em relação à incapacidade dos adultos de conseguir protegê-la da violência do agente. Então, forma-se um pacto, normalmente não explicitado, em que a vítima consente em não denunciar e o autor consente em não violentá-la de maneira mais agressiva do que as ações que já realiza, ou a finalizar suas ações, dando término ao sofrimento, ao menos quanto aos atos em si, pois as consequências continuam a ser sentidas.
}

Revista da Faculdade de Direito - UFPR, Curitiba, vol. 59, n. 3, p. 197-223, 2014. 
[...] a mãe tava lavando roupa, aí eu peguei e saí da onde minha mãe tava e entrei pra dentro de casa, ele tava com um facão na mão, hora que eu entrei ele arriou em cima de mim, era pra matar mesmo, eu peguei e, sei lá, eu criei tanta coragem assim que eu voei no braço dele e tomei o facão e sapequei ele na parede, aí eu gritei pela mãe [...] ele pegou e saiu, sumiu, disse que nesse dia ele me matava, rapidamente eu peguei e liguei pro meu tio e contei tudinho, aí meu tio foi no Conselho [Tutelar], aí pegou e foi com o Conselho [Tutelar], Polícia [...] se não fosse isso, eu tava debaixo do chão há muito tempo. Ou eu ou ele (ALVINA. Transcrição literal).

O momento de revelação de Alvina é o instante em que toma consciência de que o grau de violência que sofria poderia chegar ao extremo, à sua morte. A adolescente vinha suportando a violência física, sexual e psicológica do seu pai já havia alguns anos, mas somente com a compreensão de que corria risco de perder a vida resolveu denunciar a situação para seu tio, um parente externo ao círculo mais íntimo da família, que acabou acionando os órgãos de proteção para intervirem no caso.

Pode-se supor que o fato de Alvina conseguir contrapor-se aos intentos do seu pai representa uma estratégia de reordenamento da relação de poder instituída até aquele momento. Um ativismo pessoal da vítima que não encontrava exemplo em outros tempos e nas outras configurações de violência sofrida. Enfrentar diretamente o autor parece ter sido o estopim não apenas para posicionar-se diante do fato, mas também para projetar a necessidade da revelação extrafamiliar como única estratégia para garantir sua integridade física.

O processo de abuso de Giselda foi menos duradouro, devido às condições de apoio social que a envolviam. Ocorreu durante três a quatro meses, e então foi descoberto por outros pastores da mesma igreja que, desconfiados das atitudes do recém-chegado pastor, foram averiguar melhor e descobriram as situações de abuso sexual, entre outras questões.

[...] foi porque já tava sumindo dinheiro da igreja, também as farra tava descobrindo dele, fora que tinha outras meninas que tavam sendo abusadas [...]. Mas aí quando descobriram ele tinha acabado de viajar pra Belém, aí foi fugido, ele foi em cima de quando descobriram [...] foi aí que chamou nós e nesse mesmo dia eles foram falar com meu pai [...] aí eu morrendo de medo de num saber e aquilo tudo acontecendo e a pastora lá do meu lado e eles querendo que eu falasse a verdade, só que ele falou que quando acontecesse isso eu teria que nega e eu tendo que nega isso tava sendo horrível pra mim. Aí todo mundo falando pra mim falar a verdade que faltava só eu confirmar e eu só na minha cabeça, ele falando que eu tinha que negar, aí até que meu pai falou que eu ia fazer exame e tal, aí eu já num tava aguentando aquilo tudo, aí foi que eu falei, nossa, meu pai naquele momento, nossa! [...] tudo isso no mesmo dia, aí que chamou a Polícia, aí eu ainda fui no Conselho Tutelar, eu ainda fui na Procuradoria [Ministério Público do Estado], foi tanta coisa em dois dias e isso pra mim assim eu nem dormi e tendo que falar tudo que aconteceu durante esse tempo todo pra tantas pessoas, pra delegado, pra conselheiro, tantas pessoas, pra psicólogo, pra tanta gente que eu nunca vi, tendo que contar tudo isso, desde o começo até aquele exato momento [...] (GISELDA. Transcrição literal).

O processo de revelação de Giselda aponta para duas questões estruturais ao trabalho com vítimas de abuso sexual: a força simbólica do pacto de silêncio e o perigo da 
revitimização. Em primeiro lugar, a ameaça imposta pelo autor do abuso sexual à vítima deflagrou efeitos de medo, inibição e desconforto que se prolongaram para além dos abusos sofridos e da própria presença física do autor. Trata-se, como aponta Alvin (1997), de sintomas pós-traumáticos normalmente presentes em adolescentes em período de revelação de abuso sexual extrafamiliar, sendo necessário saber respeitar e compreender, pois, como ressalta, "muitas vezes mascaram um estado de choque que deve ser interpretado em sua justa medida" (ALVIN, 1997, p. 76).

Nesse sentido, percebe-se em tais manifestações a força simbólica do autor, travestida na resistência de Giselda em libertar-se do pacto de silêncio, ante o imperativo do temor pelas punições adicionais que pudesse sofrer (LAMOUR, 1997) - ou seja, da ciência de que o ato de revelar poderia trazer consequências negativas. Segundo Padilha e Gomide (2004), este é um dos elementos comuns do processo de revelação e terapia junto às vítimas de abuso sexual. O outro seria o desenvolvimento de sentimentos ambivalentes para com o autor do abuso, os quais precisam ser externalizados na terapia para que ocorra a desculpabilização da vítima, facilitando o trabalho de aceitação e melhoria da autoestima.

Em termos teóricos, o (re)posicionamento de Giselda e de Alvina ante as situaçõesproblema que as afligiam pode ser enquadrado no conjunto de etapas da revelação descritas por Cunningham:

[...] a) na primeira, as crianças precisam compreender que o comportamento agressivo sexual é errado [...]; b) a segunda etapa envolve que a criança supere os fatores de inibição que a impedem e dificultam em fazer a revelação; c) em seguida, as crianças precisavam decidir quando contar e isso era uma decisão muito difícil de tomar; d) a quarta etapa envolve a tomada de decisão sobre a quem elas poderiam contar a respeito do abuso sexual (CUNNINGHAM, 2011, p. 91. Grifos do autor).

Para cada uma das vítimas, a passagem por tais etapas demandou uma temporalidade singular, que remete a condições específicas propiciadoras de uma revelação marcada por aspectos positivos e negativos, mas, acima de tudo, pela capacidade de pôr um basta no(s) abuso(s) e nas relações de poder estabelecidas.

Um segundo elemento, presente de maneira marcante no relato de Giselda, é a peregrinação empreendida nos órgãos públicos para ter a intervenção estatal necessária à apuração do caso e ao atendimento da vítima. O fato de ela ter que relatar o que lhe ocorreu para tantas pessoas ou instituições revela um estado de revitimização perpetrado à vítima pelo próprio Estado.

Por revitimização entende-se, conforme a definição de Luz, Paiva e Roseno (2007, p. 11), o "processo de ampliação do trauma vivido pela vítima de violência, em função de 
procedimentos inadequadamente realizados, sobretudo por instituições oficiais, durante o atendimento da violência notificada". Conforme aduz Andreotti (2012), a revitimização

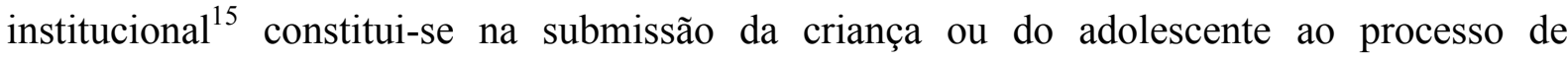
recordação das experiências abusivas, o que provoca a reemergência de sentimentos que podem causar-lhe novos danos psicológicos, complementares aos danos do abuso em si.

Fica nítida a expressão de constrangimento de Giselda ao ter que relatar o mesmo caso para tantas pessoas estranhas em tão pouco tempo, e sob um clima de extrema tensão que se manifestou fisicamente na falta de sono. A vítima foi alvo de intervenções inadequadas que, sob o afã de buscar as provas necessárias para fundamentar a acusação ao autor, acabaram subjugando a condição de sujeito de direitos de Giselda; é dizer, de alguém que deve ser transformada da condição de objeto processual para a de sujeito cujos direitos foram violados e cujo desenvolvimento biopsicossocial e sexual foi afetado de maneira drástica, cabendo aos agentes estatais o dever prioritário de protegê-la e de sanar as condições prévias de sofrimento, e não, multiplicá-las.

Paralelamente, a presença da revitimização revela a dificuldade de integração e colaboração entre os órgãos públicos (ANDREOTTI, 2012). A atuação intersetorial no atendimento das vítimas de abuso sexual é um preceito da política de atendimento instituída pelo artigo $86^{16}$ do Estatuto da Criança e do Adolescente (ECA), que preza pela municipalização do atendimento e pela intervenção que não seja centrada apenas na criança ou no adolescente individualmente, "mas também [n]a família e [n]a comunidade como um todo, abrangendo aí, fundamentalmente, o atendimento e proteção de interesses de crianças e adolescentes no meio escolar e institucional" (MARTINS, 2009, p. 53).

Da mesma forma, a Convenção sobre os Direitos da Criança (BRASIL, 1990b), no seu artigo 19, inciso 2, ao tratar das formas de enfrentamento institucional do abuso sexual, também indica a necessidade de os Estados nacionais estabelecerem medidas de proteção que incluam

[...] procedimentos eficazes para a elaboração de programas sociais capazes de proporcionar uma assistência adequada à criança e às pessoas encarregadas de seu cuidado, bem como para outras formas de prevenção, para a identificação, notificação, transferência a uma instituição, investigação, tratamento e

\footnotetext{
${ }^{15}$ Isto porque, segundo Andreotti (2012, p. 66), haveria uma primeira revitimização de cunho social que "diz respeito ao julgamento social da criança que se viu inocentemente envolvida em um rol de comportamentos ditos 'desviantes'. Reações sociais de exclusão e violência, incluindo a difamação e o rechaço social, são formas de revitimização [...]”.

16 Assim disposto: "Art. 86. A política de atendimento dos direitos das crianças e dos adolescentes far-se-á através de um conjunto articulado de ações governamentais e não-governamentais, da União, dos Estados, do Distrito Federal e dos Municípios" (BRASIL, 1990a).
} 
acompanhamento posterior dos casos acima mencionados de maus tratos à criança e, conforme o caso, para a intervenção judiciária.

Em termos práticos, a garantia da assistência adequada via trabalho intersetorial da rede de proteção envolve a qualificação dos recursos humanos e a estruturação do fluxo sistêmico de atendimento, para assegurar intervenções céleres e eficazes junto aos sujeitos do abuso sexual, sejam eles a vítima, seus familiares ou o autor, de forma a evitar a demora e/ou o prejuízo na intervenção procedida.

No processo de deflagração da denúncia e atuação dos órgãos de proteção, a composição de uma rede de competências interinstitucionais de atendimento às vítimas deve prezar, prioritariamente, pela recomposição das condições de vida das pessoas atendidas, procurando minimizar os espaços de interlocução que exijam a obtenção de informações sobre os fatos diretamente com as vítimas. Deve ainda humanizar o tratamento profissional a tais sujeitos e promover sua inserção em serviços que possibilitem o resgate e/ou fortalecimento da convivência familiar e comunitária, ou a internação, quando necessário. Em todo caso, sugere-se que as provas para definição da materialidade e autoria dos crimes sexuais sejam obtidas de maneira que evite, ao máximo, novos sofrimentos e constrangimentos às vítimas, mesmo no tocante aos exames periciais e aos depoimentos de testemunhas. O cerne está em visualizar, continuamente, que as vítimas são sujeitos de direitos em situação de violação, e não objetos para produção de provas na investigação.

O direito fundamental da criança e do adolescente, de serem protegidos de qualquer forma de violência, insere-se numa estrutura maior de compreensão da prioridade absoluta à garantia de tais direitos, a qual preza pelo reconhecimento da condição peculiar de desenvolvimento. Tal suporte normativo precisa alimentar a capacidade dos profissionais e das instituições de colocarem a melhoria das condições de vida das crianças e dos adolescentes como prioridades absolutas dos seus atendimentos, sem perder de vista o aspecto relacional da intervenção junto às famílias e às comunidades, assim como o auxílio à produção de provas para a qualificação do inquérito/processo.

Num âmbito macro estratégico, desde a formulação do I Plano Nacional de Enfrentamento da Violência Sexual Contra Crianças e Adolescentes, no ano de 2000, estimulam-se os estados e os municípios a institucionalizarem o planejamento integrado das medidas de enfrentamento multifocais à violência sexual ${ }^{17}$, visando à previsão de políticas,

\footnotetext{
${ }^{17}$ A elaboração do plano em si constitui-se como uma medida de planejamento integrado para a qualificação do enfrentamento da violência sexual contra crianças e adolescentes em determinado território de jurisdição das instituições e entidades envolvidas. Além disso, tanto o referido Plano Nacional, de 2000, quando o II Plano Revista da Faculdade de Direito - UFPR, Curitiba, vol. 59, n. 3, p. 197-223, 2014.
} 
recursos e competências que qualifiquem substancialmente o diagnóstico e a intervenção sobre as situações-problema e as condições dos serviços ofertados.

Em Altamira, no período de coleta de dados para a presente pesquisa, ocorria, paralelamente, a elaboração do Plano Municipal de Enfrentamento da Violência Sexual Contra Crianças e Adolescentes, em vigência desde maio de 2012. Em setembro de 2013, o município elaborou três fluxos de atendimento voltados as seguintes dinâmicas da violência sexual contra crianças e adolescentes: abuso sexual; exploração sexual; e, abuso sexual no contexto de povos indígenas e comunidades ribeirinhas ${ }^{18}$. As estratégias foram concebidas com ampla participação de representantes da Comissão Municipal de Enfrentamento da Violência Sexual Contra Crianças e Adolescentes de Altamira.

\section{TRATAMENTO PSICOSSOCIAL}

Quando se fala em tratamento psicossocial é preciso ter cuidado com a forma de abordagem da intervenção terapêutica voltada aos danos subjetivos causados pelo abuso sexual, evitando abordá-los pela ótica da ação para a superação, ante a consciência de que o enfoque interventivo está na preparação dos sujeitos para saber lidar com os traumas e os sintomas provenientes da situação, assim como no fortalecimento da autoestima e da autoproteção (PADILHA; GOMIDE, 2011).

O tratamento das duas entrevistadas foi desenvolvido no CREAS/Altamira, procedente de encaminhamentos do Conselho Tutelar de Direito de Altamira. O ingresso das entrevistadas no atendimento psicossocial engendra a produção de um conjunto de expectativas, sentimentos e relações intersubjetivas que são afetados e passam a influir sobre a subjetividade da pessoa que adentra a instituição para receber o atendimento, como se percebe nos relatos a seguir:

[...] aí eu peguei e fui com atendimento pelo CREAS, foi super bacana, eu conheci o doutor (psicólogo. Nota do autor), as meninas lá [...] aí eu já me mudei aqui pra Altamira, fiquei até setembro, se não me engano, na casa do meu tio [...] aí eu voltei

Nacional de Enfrentamento da Violência Sexual Contra Crianças e Adolescentes, de maio de 2013, apresentam propostas específicas, em seus diversos eixos de atuação, voltadas para o trabalho intersetorial.

${ }^{18}$ A disposição de um fluxo específico para os casos de abuso sexual envolvendo membros de povos indígenas e comunidades ribeirinhas representa uma inovação procedimental e institucional que parte do reconhecimento dos desafios e das especificidades do trabalho da rede de proteção junto à diversidade cultural de grupos étnicos existentes na região amazônica; mais precisamente, no município de Altamira. Para tanto, o fluxo étnico internaliza aportes normativos dos direitos internacionais de povos e comunidades tradicionais presentes na Convenção $n^{\circ} 169$ da Organização Internacional do Trabalho (OIT) e reforça a necessidade do trabalho interdisciplinar e intercultural, com o suporte de antropólogos e/ou de lideranças indígenas que melhorem a compreensão dos fatos e das possíveis formas de intervenção e soluções a serem empreendidas. Sobre o assunto, cf. Harris-Short (2011), Long e Sephton (2011) e Oliveira (2014a e 2014b).

Revista da Faculdade de Direito - UFPR, Curitiba, vol. 59, n. 3, p. 197-223, 2014. 
lá pra comunidade, aí eu ficava vindo pro CREAS, direto eu vinha, voltava, tinha vez que eu vinha no final de semana, ficava aqui [...] foi o doutor (psicólogo. Nota do autor) mesmo que me recebeu, o primeiro que eu conheci lá dentro foi ele mesmo [...] foi super bacana [...] me ajudou bastante [...] com a assistente social eu fui só uma vez, mas só que eu não me lembro o nome dela [...] é só, eu vinha cedo e quando dava onze horas eu ia embora de novo [...] (ALVINA. Transcrição literal).

Já Giselda afirma que:

[...] me encaminharam lá pro CREAS pra mim fazer acompanhamento lá com psicóloga [...] aí eles foram lá em casa e disse que ia fazer meu acompanhamento, foi muito difícil pra mim aceitar o CREAS sabe, que eu já não falava muito, aí ter que ficar falando, foi difícil oh, foi uma mudança radical, completamente, assim, de um tapa pra mim mudar, porque eu sabia que mudanças depois ia acontecer na minha vida, mas não assim de uma vez só... aí foi que eu tava começando o acompanhamento aí depois a (psicóloga) mudou, aí foi com o [psicólogo], aí depois que eu tive mais tempo foi com o [psicólogo], aí foi que ele me ajudando foi que eu fui esquecendo $[\ldots]$ acho que o tratamento durou uns oito meses [...] o CREAS pra mim foi a inovação da minha vida, foi lá que eu fui recebida, fui atendida bem, aprendi as coisas da vida, que eles me mostraram de um jeito mais fácil pra mim entender, que esse problema num acabou com minha vida né, aliás ele recomeçou a minha vida de novo, talvez do jeito mais horrível, mas que agora eu tenho que viver, e que eu fui a vítima, que isso vai passar [...] porque eu acho que se não tivesse ido pro CREAS eu acho que eu tinha me matado [...] (GISELDA. Transcrição literal).

Saber lidar com o fato e suas consequências, daí reinventando a própria compreensão de si mesmas, de sua autoestima e valor humano, são questões que perpassam os relatos das duas entrevistadas. Ao mesmo tempo, aparece a representação simbólico-afetiva do CREAS, não como uma instituição, no sentido objetivo do termo, mas de lugar onde ocorreram relações intersubjetivas entre as vítimas e os profissionais, interações reconhecidas, posteriormente, como fundamentais para o desenvolvimento de mudanças positivas na autoestima e no comportamento, fazendo-as ressignificar o passado traumático para dar andamento às suas vidas.

Para Pinheiro e Fornari (2011, p. 311), os sentimentos despertados fazem parte de uma eleição de técnicas de tratamento psicológico que "possam conferir um lugar psíquico aos afetos e às marcas traumáticas e patogênicas que obliteram a possibilidade de devir subjetivo". A reconstrução dos laços sociais e da confiança no outro, especialmente quando este é o grupo familiar, é facilitada pela estruturação de um ambiente especial de atendimento, em que o psicólogo atue de forma a promover laços confiáveis visando à estruturação de um cenário "de antigas e novas experiências emocionais, que privilegie a sustentação, o olhar, a escuta, a instrumentação das comunicações não verbais e o jogo transferencial/contratransferencial” (PINHEIRO; FORNARI, 2011, p. 312).

No entanto, percebe-se também a presença única e constante da Psicologia no campo de atenção às vítimas, revelando a inexistência do trabalho interdisciplinar conforme 
preceituam o Estatuto da Criança e do Adolescente ${ }^{19}$ e as regras de constituição da equipe do CREAS $^{20}$. Dado o fato de o abuso sexual possuir uma multicausalidade de características e formas de afetação às vítimas, é evidente a necessidade de trabalho articulado de múltiplos campos profissionais (e de instituições em rede) para o estabelecimento de uma microrrede de atuação protetiva com maior probabilidade de apoiar as vítimas, além de garantir o suporte mútuo entre os profissionais.

\section{PERSPECTIVAS DE VIDA PÓS-ATENDIMENTO}

Foi possível perceber, nos dois casos, que as jovens continuaram com expectativas de vida, sobretudo quanto ao estudo e à convivência matrimonial, não deixando que os traumas dos abusos sofridos as impedissem, até o momento, de seguir adiante. E, segundo elas relatam, isso é devido, em grande parte, ao tratamento obtido no CREAS.

Alvina se encontra atualmente em Altamira, trabalhando em casa de família, cursando o primeiro ano do ensino médio e namorando um rapaz que ela afirma lhe fazer muito bem.

Ela passou a morar na cidade de Altamira, e não mais na comunidade rural, devido ao fato de o autor do abuso sexual (seu pai) ter sido libertado da prisão temporária, via mandado de liberdade provisória, e ter voltado a morar novamente no que, agora, é a antiga casa dela, como relata:

[...] quando foi agora dia 16 de fevereiro [de 2012] ele saiu [...] aí eu vim-me embora pra cá pra Altamira [...], eu vim-me embora, se eu ficasse lá eu tinha certeza que eu ia matar ele, e antes de eu sair eu falei, deixei bem claro, 'trisca um dedo na minha mãe eu volto e te mato', e eu mato mesmo (ALVINA. Transcrição literal).

O retorno do autor da agressão, para morar novamente na mesma casa em que produzia os abusos, coloca uma série de reflexões em questão. Em primeiro lugar, o direito à convivência familiar e comunitária de Alvina passa a ser frontalmente violado, na medida em

\footnotetext{
${ }^{19}$ As diretrizes da política de atendimento presentes nos artigos 86 a 89 do ECA (BRASIL, 1990a), relativas à articulação interinstitucional, municipalização dos serviços e participação popular, reordenaram a tutela institucional das crianças e dos adolescentes ao erigir a integração entre as diferentes instituições, profissionais e segmentos sociais como o aspecto elementar de constituição da rede de proteção, cujo papel social é resguardar e/ou restituir os direitos conferidos às crianças e aos adolescentes. Sobre o assunto, cf. Pinheiro e Fornari (2011), Rossato, Lépore, e Sanches (2013) e Tavares (2010).

${ }^{20}$ A identificação, tipificação e regulamentação dos serviços socioassistenciais de caráter especializado prestados pelo CREAS estão estipulados, principalmente, na Lei $n^{\circ}$ 8742/1993 (Lei Orgânica da Assistência Social/LOAS), na Lei $n^{\circ} 12435 / 2011$ e na Política Nacional da Assistência Social, de 1994. Todas elas identificam a obrigatoriedade de um trabalho interdisciplinar de atendimento psicossocial, educativo e jurídico, visando à intervenção qualificada sobre os diversos âmbitos das situações de risco e violência que afetam as crianças e os adolescentes, assim como mulheres, idosos, pessoas com deficiência e moradores de rua.
}

Revista da Faculdade de Direito - UFPR, Curitiba, vol. 59, n. 3, p. 197-223, 2014. 
que não encontra suporte familiar e institucional para permanecer em sua casa. $O$ regresso de seu pai à casa implica uma segunda agressão a Alvina: a impossibilidade de permanência no mesmo local que ele, e, nesse caso, de (quase) obrigatoriedade de sair do recinto para que possa voltar a ter uma vida normal, ao menos no que diz respeito a evitar novas formas de violência por parte de seu pai.

A volta do autor ao ambiente familiar demonstra a complexidade que envolve as dinâmicas de convivência familiar em casos de abuso sexual. O afastamento do autor, da moradia comum, é uma possibilidade jurídica definida no artigo $130^{21}$ do ECA, de mesma forma que as medidas de proteção de acolhimento institucional, familiar ou por família substituta para a criança/adolescente impossibilitada de reintegração familiar, nos ditames do artigo $101^{22}$ do mesmo diploma legal. Porém, o que sobressai do relato de Alvina, além da ausência de qualquer intervenção institucional que pudesse sanar tal problema, é o agenciamento da situação adversa pela adolescente, que identificou, no ato de sair de casa e de ameaçar o autor, possibilidades de ação autoprotetiva frente à situação instaurada, revelando um protagonismo de enfrentamento da nova violação que, evidentemente, cobra seu preço, no afastamento dos vínculos familiares e da continuidade dos riscos de violências para com seus outros familiares que permanecem na casa.

Certamente não se questiona, aqui, a liberdade provisória obtida pelo pai para sair da prisão preventiva, uma vez que se trata de um instituto legal que prevê o afastamento de um lugar que pouco, ou nada, tem a contribuir para sua melhoria enquanto ser humano - a dita ressocialização. O ponto a ser discutido é a não existência de políticas sociais de caráter protetivo que incidam sobre esta questão em favor das vítimas, pois a inversão da prioridade de fortalecimento de vínculo familiar existente no caso de Alvina - a sua saída para que o autor permaneça, junto à família - revela um novo processo de revitimização e de desamparo familiar, para além de todo o agenciamento que a vítima possa ter.

As instituições da rede de proteção necessitam atentar para tal contexto do processo de intervenção sobre casos de abuso sexual, especialmente os intrafamiliares, que é o da saída do autor do encarceramento temporário (ou do definitivo), o qual produz a possibilidade de novos contatos entre vítima e autor, algo que necessita de um suporte político-institucional,

\footnotetext{
${ }^{21}$ Assim descrito: “Art. 130. Verificada a hipótese de maus-tratos, opressão ou abuso sexual impostos pelos pais ou responsável, a autoridade judiciária poderá determinar, como medida cautelar, o afastamento do agressor da moradia comum" (BRASIL, 1990a).

${ }^{22}$ Da seguinte forma: “Art. 101. Verificada qualquer das hipóteses previstas no art. 98, a autoridade competente poderá determinar, dentre outras, as seguintes medidas: [...] VII - acolhimento institucional; VIII - inclusão em programa de acolhimento familiar; IX - colocação em família substituta" (Ibid.). 
por parte da rede de proteção, para promover a reconciliação dos vínculos, quando possível, e resguardar a prioridade absoluta dos direitos das crianças e dos adolescentes.

Seja como for, o fato é que tal questão não impede Alvina de realizar projetos para sua vida:

[t]enho vontade de me formar engenheira agrônoma. Tinha vontade de estudar mecânica também, mas tem muitas peças e de quebra-cabeça já basta minha vida. Ou então veterinária, gosto muito de animal [...] (ALVINA. Transcrição literal).

Já Giselda continua morando na mesma residência, com seu pai, mãe, irmãos e sobrinhos, e mantém o andamento nos estudos, cursando atualmente o segundo ano do ensino médio. Ela demonstra gosto pelo ensino superior e os pais a apoiam muito nesse sentido.

[...] Penso em fazer Administração [...] eu fico pensando, uma coisa que eu assim quero me profissionalizar, uma coisa que eu quero fazer, né, acabei pensando em Medicina, mas num foi o que eu... aí pensei em tantas outras mais não foi o que eu senti "ah, é isso que eu quero", aí quando eu vi assim Administração, Administração de Empresa que eu quero fazer, aí eu 'ah, é isso que eu quero fazer', é isso que tem na minha cabeça até então [...] (GISELDA. Transcrição literal).

O estudo, visto anteriormente, na representação da escola, com identificações negativas, é retrabalhado, de maneira positiva, na perspectiva da universidade e das projeções de atuação profissional. A identificação da continuidade dos estudos como algo referencial para a retomada dos projetos de vida estabelece a expressão de sentimentos positivos que contribuem para a reconstrução da rotina e para a criação de novos objetivos de vida.

Para tanto, o tratamento psicossocial obtido no CREAS teve o papel central de fornecer subsídios para a resiliência e o fortalecimento da autoestima das vítimas, as quais ressignificaram sua própria condição de vítimas de abuso sexual para buscar novos elementos que as fizessem confiar nos outros e em si mesmo, de tal forma eficaz que possibilitou a uma delas estabelecer laços amorosos com um homem.

\section{CONSIDERAÇÕES FINAIS}

Da violência ao atendimento, várias histórias de vida são entrelaçadas para compor os enredos (inter)subjetivos das duas adolescentes, marcados por sofrimentos, marcas físicas, lembranças, coragens e mudanças. A trajetória de cada uma delas revela a presença de fatores de risco na infância - pobreza, baixa escolaridade dos pais e dificuldade/ausência na escola que possuem entonações variadas, mas presentes, de influência nos abusos sexuais acometidos. 
O processo de revelação, pela vítima, do abuso sexual sofrido, demonstra quão difícil é o trabalho pessoal de publicizar informações sobre os fatos do abuso, com sinais nítidos de conformação simbólica de um pacto de silêncio entre vítima e autor - por vezes envolvendo os familiares - que perdura ao longo do tempo e possui consequências mesmo depois da revelação. Por outro lado, a intervenção institucional nos casos analisados apresenta uma dupla deficiência do trabalho integrado: em primeiro, da articulação da rede para garantir um atendimento que, ao menos no caso de Giselda, não a forçasse a relembrar e contar várias vezes as situações vivenciadas, evitando-se a revitimização; paralelamente, percebe-se que o atendimento psicossocial obtido no CREAS deveu-se apenas à atuação do profissional da Psicologia, em vez de uma equipe interdisciplinar.

Em ambos os casos, a melhoria da atuação em rede e do trabalho interdisciplinar intrainstitucional percorreriam um caminho de melhoria de políticas públicas que perpassa desde a qualificação continuada dos profissionais e a ampliação dos recursos humanos até o estabelecimento de fluxos de atendimento que organizem e deem segurança para os atendimentos e encaminhamentos a serem feitos em casos de abuso sexual. Tal melhoria representa a exigibilidade de cumprimento dos preceitos estabelecidos nos direitos das crianças e dos adolescentes, constituindo-se numa mudança progressiva da qualidade de atendimento da rede de proteção.

Ainda assim, pode-se concluir que Alvina e Giselda conseguiram reverter a situação adversa do abuso, estabelecendo projetos de vida assentados no estudo e nas relações afetivoconjugais que evidenciam, com base nos dados obtidos, um sucesso no atendimento terapêutico obtido no CREAS e uma projeção de futuros que produzam lembranças e vivências melhores dos que as vividas no passado.

\section{REFERÊNCIAS}

ALBUQUERQUE JÚNIOR, Roberto Paulino de. A filiação socioafetiva no direito brasileiro e a impossibilidade de sua desconstituição posterior. In: Jus Navigandi, Teresina, ano 11, n. 1547, set. 2007. Disponível em: <http://jus2.uol.com.br/doutrina/texto.asp?id=10456>. Acesso em: 20 ago. 2008.

ALVIN, Patrick. Os adolescentes vítimas de abusos sexuais. In: GABEL, Marceline (Org.). Crianças vítimas de abuso sexual. São Paulo: Summus, p. 72-81, 1997.

ANDREOTTI, Cristiane. Enfrentamento da revitimização: a escuta de crianças vítimas de violência sexual. São Paulo: Casa do Psicólogo, 2012. 
BOURDIEU, Pierre. A ilusão biográfica. In: FERREIRA, Marieta de Moraes; AMADO, Janaína. (Org.). Usos \& abusos da história oral. Rio de Janeiro: Editora FGV, p. 183-91, 2006.

BRASIL. Constituição da República Federativa do Brasil de 1988. Diário Oficial da União, Brasília, DF, 05 out. 1988. Disponível em:

$<$ http://www.planalto.gov.br/ccivil_03/constituicao/Constituicao.htm>. Acesso em: 20 nov. 2011.

. Decreto $\mathrm{n}^{\circ}$ 99.710, de 21 de novembro de 1990. Promulga a Convenção sobre os Direitos da Criança. Diário Oficial da União, Brasília, DF, 22 nov. 1990 (1990b). Disponível em: <http://www.planalto.gov.br/ccivil_03/decreto/1990-1994/D99710.htm>. Acesso em: 26 out. 2014.

. Exploração sexual infantil. Brasília: Secretaria de Direitos Humanos da Presidência da República, 2013.

. Lei $\mathrm{n}^{\mathrm{o}} 8.069$ de 13 de julho de 1990. Dispõe sobre o Estatuto da Criança e do Adolescente e dá outras providências. Diário Oficial da União, Brasília, DF, 16 jul. 1990 (1990a). Disponível em: <http://www.planalto.gov.br/ccivil_03/leis/18069.htm>. Acesso em: 20 nov. 2011.

. Lei $n^{0}$ 8.742, de 7 de dezembro de 1993. Dispõe sobre a organização da Assistência Social e dá outras providências. Diário Oficial da União, Brasília, DF, 8 dez. 1993. Disponível em: <http://www.planalto.gov.br/ccivil_03/leis/18742.htm>. Acesso em: 20 nov. 2011.

Lei $\mathrm{n}^{\mathrm{o}}$ 12.435, de 6 de julho de 2011. Altera a Lei no 8.742, de 7 de dezembro de 1993, que dispõe sobre a organização da Assistência Social. Diário Oficial da União, Brasília, DF, 7 jul. 2011. Disponível em: <http://www.planalto.gov.br/ccivil_03/_Ato20112014/2011/Lei/L12435.htm>. Acesso em: 20 nov. 2011.

Ministério do Desenvolvimento Social e Combate à Fome. PNAS - Política Nacional de Assistência Social - Institucional (A PNAS foi aprovada em 22 de setembro de 2004, pelo Conselho Nacional de Assistência Social). Disponível em: $<$ http://www.mds.gov.br/falemds/perguntas-frequentes/assistencia-social/assistenciasocial/usuario/pnas-politica-nacional-de-assistencia-social-institucional $>$. Acesso em: 20 nov. 2011.

CUNNINGHAM, Alison. A escuta de crianças abusadas sexualmente para compreensão do processo de revelação. In: WILLIAMS, Lúcia Cavalcanti de Albuquerque; ARAÚJO, Eliane Aparecida Campanha (Org.). Prevenção do abuso sexual infantil: um enfoque interdisciplinar. Curitiba: Juruá, 2011, p. 84-97.

DIAS, Maria Berenice. Manual de direito das famílias. 4. ed. São Paulo: Revista dos Tribunais, 2007.

EROLIN, Kara S.; WIELING, Elizabeth; PARRA, R. Elizabeth Aguilar. Family violence exposure and associated risk factors for child PTSD in a Mexican sample. In: Child Abuse \& Neglect, 38, 2014, p. 1011-22. 
GOMIDE, Paula Inez Cunha; PADILHA, Maria da Graça Saldanha. Destituição do poder familiar e prisão do agressor em um caso de abuso sexual intrafamiliar. In: WILLIAMS, Lúcia Cavalcanti de Albuquerque; ARAÚJO, Eliane Aparecida Campanha (Org.). Prevenção do abuso sexual infantil: um enfoque interdisciplinar. Curitiba: Juruá, 2011, p. 98-111.

GROENINGA, Giselle Câmara. Família: um caleidoscópio de relações. In: GROENINGA, Giselle Câmara; PEREIRA, Rodrigo da Cunha (Org.). Direito de família e psicanálise: rumo a uma nova epistemologia. Rio de Janeiro: Imago, 2003, p. 125-42.

HARRIS-SHORT, Sonia. Aboriginal child welfare, self-government and the rights of indigenous children: protecting the vulnerable under international law. Surrey: Ashgate, 2012.

LACAN, Jacques. A família. Tradução Brigitte Cardoso e Cunha. Lisboa: Assirio \& Alvim, 1981.

LACERDA, Paula Mendes. $O$ "caso dos meninos emasculados de Altamira": Polícia, Justiça e Movimento Social. Tese (Doutorado). Rio de Janeiro: UFRG/Museu Nacional, 2012. 328 fls.

. Polícia e movimento social em Altamira, Pará: o "caso dos meninos emasculados". In: VIANNA, Adriana (Org.). O fazer e o desfazer dos direitos: experiências etnográficas sobre político, administração e moralidades. 1. ed. Rio de Janeiro: E-papers, 2013, p. 147-83.

A luta pelos direitos da infância em Altamira. In: OLIVEIRA, Assis da Costa; PINHO, Vilma Aparecida de (Org.). Direitos das crianças e dos adolescentes: violência sexual, medidas socioeducativas, diversidade étnicorracial e movimentos populares. Belém: Supercores Editora, 2014, p. 195-218.

LAMOUR, Martine. Os abusos sexuais em crianças pequenas: sedução, culpa e segredo. In: GABEL, Marceline (Org.). Crianças vítimas de abuso sexual. São Paulo: Summus, p. 43-61, 1997.

LANDINI, Tatiana Savoia. O professor diante da violência sexual. São Paulo: Cortez, 2011.

LONG, Maurren; SEPHTON, Rene. Rethinking the "Best Interests" of the Child: Voices from Aboriginal Child and Family Welfare Practitioners. In: Australian Social Work, v. 64, n. 1, mar. 2011, p. 96-112.

LÓPEZ, María Cecilia. Abuso sexual: cómo prevernilo, cómo detectarlo. Buenos Aires: Paidos, 2010.

LUZ, Fernando; PAIVA, Leila; ROSENO, Renato. Proteger e responsabilizar - O desafio da resposta da sociedade e do Estado quando a vítima da violência sexual é criança ou adolescente. In: BRASIL. Proteger e responsabilizar: o desafio quando a vítima da violência sexual é criança ou adolescente. Brasília: Comitê Nacional de Enfrentamento da Violência Sexual Contra Crianças e Adolescentes, mai. 2012, p. 7-52. Disponível em: $<$ http://www.nre.seed.pr.gov.br/patobranco/arquivos/File/Permanente/Equipe\%20Disciplinar/ Ciencias/Textos2013/ProtegerLivro.pdf >. Acesso em: 28 jun. 2014. 
MARTINS Daniele Comin. Estatuto da Criança e do Adolescente \& Política de Atendimento. Curitiba: Juruá, 2009.

OLIVEIRA, Assis da Costa. Indígenas crianças, crianças indígenas: perspectivas para construção da Doutrina da Proteção Plural. Curitiba: Juruá, 2014a.

De grão em grão: implantação da metodologia PAIR no município de Altamira. In: OLIVEIRA, Assis da Costa; PINHO, Vilma Aparecida de (Org.). Direitos das crianças e dos adolescentes: violência sexual, medidas socioeducativas, diversidade étnico-racial e movimentos populares. Belém: Supercores Editora, 2014b, p. 21-56.

; PINHO, Vilma Aparecida de (Coord.). Relatório final do Diagnóstico Rápido Participativo Complementar: enfrentamento da violência sexual contra crianças e adolescentes em Altamira/PA. Altamira: s/n, 2014. Disponível em: <www.pair.ledes.net>. Acesso em: 29 jun. 2014.

PADILHA, Maria da Graça Saldanha; WILlIAMS, Lúcia Cavalcanti de Albuquerque. Intervenção escolar para prevenção do abuso sexual com estudantes pré-adolescentes e adolescentes. In: WILLIAMS, Lúcia Cavalcanti de Albuquerque; ARAÚJO, Eliane Aparecida Campanha (Org.). Prevenção do abuso sexual infantil: um enfoque interdisciplinar. Curitiba: Juruá, 2011, p. 128-35.

PEDERSEN, Jaina Raqueli; GROSSI, Patrícia Krieger. O abuso sexual intrafamiliar e a violência estrutural. In: AZAMBUJA, Maria Regina Fay de et al. Violência sexual contra crianças e adolescentes. Porto Alegre: Artmed, 2011, p. 25-34.

PEREIRA, Rodrigo da Cunha. Direito de família: uma abordagem psicanalítica. 3. ed. Belo Horizonte: Del Rey, 2003.

PINHEIRO, Lucilene de Souza; FORNARI, Vera Lúcia. O papel do psicólogo nos casos de violência contra a criança e o adolescente. In: AZAMBUJA, Maria Regina Fay de et al. Violência sexual contra crianças e adolescentes. Porto Alegre: Artmed, 2011, p. 298-317.

PINHO, Vilma Aparecida de e OLIVEIRA, Assis da Costa (Coord.). Relatório final do Diagnóstico Rápido Participativo: enfrentamento da violência sexual contra crianças e adolescentes em Altamira/PA. Altamira: s/n, 2013. Disponível em: <www.pair.ledes.net>. Acesso em: 29 jun. 2014.

ROSSATO, Luciano Alves; LÉPORE, Paulo Eduardo; CUNHA, Rogério Sanches. Estatuto da Criança e do Adolescente comentado: Lei 8.069/1990: artigo por artigo. 5. ed. São Paulo: Editora Revista dos Tribunais, 2013.

ROYER, Michèle. As crianças vítimas, consequências a curto e médio prazo. In: GABEL, Marceline (Org.). Crianças vítimas de abuso sexual. São Paulo: Summus, 1997, p. 62-71.

SAHIN, Z. Seda; MACVICKER, Melissa L. An integration of narrative therapy and positive psichology with sexual abuse survivors. In: BRYANT-DAVIS, Thema (Ed.). Surviving sexual violence: a guide to recovery and empowerment. Maryland: Rownam \& Littlefield Published, 2011, p. 217-35. 
SANTOS, Benedito R.; IPPOLITO, Rita. Guia Escolar: identificação de sinais de abuso e exploração sexual de crianças e adolescentes. Rio de Janeiro: Seropédica/EDUR, 2011.

SANTOS, Samara Silva dos; DELL'AGLIO, Débora Dalbosco. Revelação do Abuso Sexual Infantil: reações maternas. In: Psicologia: Teoria e Pesquisa, v. 25, n. 1, jan-mar 2009, p. 8592.

TAVARES, Patrícia Silveira. A política de atendimento. In: MACIEL, Kátia (Coord.). Curso de direito da criança e do adolescente: aspectos teóricos e práticos. 4. ed. Rio de Janeiro: Lumen Juris, 2010, p. 297-352.

VIEIRA, Sandra da Silva; OLIVEIRA, Assis da Costa. Enfrentamento da violência sexual contra crianças e adolescentes no contexto de Altamira/PA: articulação político-institucional e ações sociais. In: PINHO, Vilma Aparecida de; OLIVEIRA, Assis da Costa (Org.). Direitos infanto-juvenis e violência sexual em contexto de grandes obras: reflexões e perspectivas. Belém: GTR, 2014, p. 99-110.

\section{PLOTLINES OF SEXUAL ABUSE: ANALYSIS OF PROCESS OF VIOLENCE AND CARE OF ADOLESCENTS IN THE MUNICIPALITY OF ALTAMIRA/PA}

ABSTRACT: This article aims to analyze the complexities involving the production process of sexual abuse and forms of institutional care, based on the analysis of the life history of two teenage girls, sexually abused in the municipality of Altamira, Pará state, where they reside. Firstly, it discusses the historical reality of sexual abuse in that municipality, paying attention to the case of the emasculated boys and to the current scenario influenced for the construction of the Hydroelectric Plant of Belo Monte, and conceptually defines sexual abuse. Subsequently, it analyzes the childhood of the two teenagers, noting the presence of risk factors that favor occurrence of sexual abuse. The violence cases, whose symbolic force remained beyond the act of revelation, did promote silence pacts between the rapists and their victims. Still, the uncovering, in both cases, was due to different strategies facing the abuse suffered, which finally led to inter-institutional intervention that, in its turn, led to the production of revictimization, as well as the provision of psychosocial care from a single scientific area - Psychology - without ensure interdisciplinary work. However, the abused adolescents emphasized the positive character of psychosocial intervention, whose main result was the fact that they managed to reframe the suffered violence and to establish new life projects.

KEYWORDS: Institutional intervention. Life history. Rights of children and adolescents. Sexual abuse. Sexual violence.

Recebido: 18 de julho de 2014

Aprovado: 30 de outubro de 2014 